\title{
Kajian Pengembangan Usaha Budidaya Rumput Laut Di Pantai Kutuh, Badung, Provinsi Bali
}

\author{
Ayu Putu Wiweka Krisna Dewi ${ }^{a *}$ dan Suprabadevi Ayumayasari Saraswati ${ }^{a}$ \\ ${ }^{a}$ Program Studi Manajemen Sumberdaya Perairan, Fakultas Kelautan dan Perikanan, Universitas Udayana, Badung, Bali \\ * Penulis koresponden. Tel.: +62-857-3038-8806 \\ Alamat e-mail: ayuputu72@gmail.com
}

Diterima (received) 11 Desember 2015; disetujui (accepted) 6 Januari 2016; tersedia secara online (available online) 9 Januari 2016

\begin{abstract}
Seaweed farming is one of the leading commodity fishery in Badung. One of the areas that develop seaweed farming is Kutuh Beach, Village Kutuh, District of South Kuta, Badung. Kutuh beach is better known as the Pandavas beach developed into a tourist area. That development could be affect the development of seaweed farming that already exists, but the farmers still maintain the development of seaweed farming. Based on the survey results revealed that the characteristics of seaweed farmers in Kutuh Beach is: (1) age of farmers is still relatively productive, (2) most of the educational level farmers is a high school graduate, (3) the main work of farmers are cultivating seaweed Halymenia sp. and a second job is to raise cattle, fishermen, tour guides and project workers. Based on the research data, it is known that the water quality of the growth and cultivation of seaweed Halymenia sp. relatively good but the development of seaweed farming Halymenia sp. having problems marketing.
\end{abstract}

Keywords: Halymenia sp.; seaweed; aquaculture; kutuh beach

\begin{abstract}
Abstrak
Usaha budiaya rumput laut merupakan salah satu komoditas unggulan perikanan yang sebagian besar masih ditekuni oleh masyarakat peisisr di Kabupaten Badung. Salah satu wilayah yang merupakan pusat pengembangan budidaya rumput laut adalah di Kecamatan Kuta Selatan, Kabupaten Badung yaitu tepatnya di Pantai Kutuh, Desa Kutuh. Pantai kutuh yang sekarang dikenal sebagai Pantai Pandawa berkembang menjadi daerah pariwisata. Perkembangan itu dapat mempengaruhi perkembangan usaha budidaya rumput laut yang sudah ada sebelumnya, namun pembudidaya tetap mempertahankan pengembangan usaha budidaya rumput laut. Berdasarkan hasil penelitian diketahui bahwa karakteristik pembudidaya rumput laut yang ada di Pantai Kutuh adalah (1) umur pembudidaya masih tegolong produktif, (2) sebagian besar tingkat pendidikan pembudidaya adalah lulusan SMA, (3) pekerjaan utama pembudidaya ada budidaya rumput laut jenis Halymenia sp. dan pekerjaan sampingan pembudidaya adalah beternak sapi, nelayan, pemandu wisata dan buruh proyek. Berdasarkan data hasil penelitian, diketahui bahwa pertumbuhan dan kualitas air budidaya rumput laut jenis Halymenia sp. tergolong baik, namun pengembangan usaha budidaya rumput laut jenis Halymenia sp. mengalami kendala dalam hal pemasaran rumput laut kering hasil budidaya.
\end{abstract}

Kata Kunci: Halymenia sp.; rumput laut; budidaya; pantai kutuh

\section{Pendahuluan}

Rumput laut merupakan salah satu komoditas utama perikanan budidaya yang bernilai ekonomis tinggi dengan peluang pasar yang luas, baik pasar lokal maupun ekspor. Rumput laut dapat dibudidayakan secara masal sehingga menjadi salah satu komoditas strategis dalam program revitalisasi perikanan yang dicanangkan Kementerian Kelautan dan Perikanan. Volume produksi perikanan budidaya rumput laut adalah sebesar 1.944 .800 ton atau $55.07 \%$ dari total produksi budidaya. Produksi tersebut merupakan produksi terbesar dari total produksi perikanan budidaya di Indonesia (KKP, 2011).

Budidaya rumput laut memiliki peranan penting dalam usaha meningkatkan produksi perikanan untuk memenuhi kebutuhan pangan dan gizi, memperluas kesempatan kerja, meningkatkan pendapatan dan kesejahteraan nelayan dan petani ikan serta menjaga kelestarian sumber hayati perairan (Aslan, 1998). Usaha budiaya rumput laut merupakan salah satu komoditas unggulan perikanan yang sebagian besar masih ditekuni oleh masyarakat peisisr di Kabupaten Badung. Salah satu wilayah yang merupakan pusat pengembangan budidaya rumput laut adalah di Kecamatan Kuta Selatan, Kabupaten Badung yaitu tepatnya di Pantai Kutuh, Desa Kutuh.

Desa Kutuh memiliki potensi laut yang cukup luas dalam pengembangan usaha perikanan khususnya untuk budidaya rumput laut yang selama ini telah mampu mengangkat perekonomian masyarakat yang ada di Desa Kutuh. Arthana $d k k$. (2012) menyatakan bahwa wilayah perairan tenggara pulau Bali layak digunakan sebagai lokasi budidaya rumput laut, salah satunya adalah Perairan Pantai Kutuh, Badung. Suwariyati, dkk. (2014) menambahkan bahwa jenis rumput laut yang dibudidayakan di Pantai Kutuh adalah Eucheuma cottonii dan Eucheuma spinosum. 
Pantai kutuh yang sekarang dikenal sebagai Pantai Pandawa berkembang menjadi daerah pariwisata. Perkembangan itu dapat mempengaruhi perkembangan usaha budidaya rumput laut yang sudah ada sebelumnya, namun pembudidaya tetap mempertahankan pengembangan usaha budidaya rumput laut (Suwariyati, dkk., 2014). Perkembangan pantai kutuh menjadi daerah pariwisata tentu dapat berpengaruh terhadap perkembangan usaha budidaya rumput laut yang sudah ada sebelumnya. Sumariadhi dan Wijayasa (2012) mengatakan bahwa perkembangan pariwisata pada suatu daerah dapat menyebabkan beberapa masalah lingkungan, salah satunya adalah masalah limbah yang dihasilkan dari kegiatan pariwisata. Hal tersebut menarik untuk dilakukan kajian terkait pengembangan budidaya rumput laut yang ada di pantai kutuh pada kondisi pantai kutuh yang berkembang menjadi daerah pariwisata. Penelitian ini membahas tentang karakteristik pembudidaya rumput laut yang ada di Pantai Kutuh, identifikasi kegiatan budidaya rumput laut yang dilakukan di Pantai Kutuh dan analisis pengembangan usaha budidaya rumput laut yang dilakukan di Pantai Kutuh

\section{Metode Penelitian}

\subsection{Lokasi dan Waktu Penelitian}

Penelitian ini dilaksanakan di Pantai Kutuh, Desa Kutuh, Kecamatan Kuta Selatan, Kabupaten Badung. Pengambilan data wawancara terhadap pembudidaya rumput laut, pertumbuhan dan kualitas air budidaya rumput laut di pantai kutuh dilakukan pada bulan Juni 2015.

\subsection{Metode Pengumpulan Data}

Data yang dikumpulkan dalam penelitian ini terdiri dari data umur, tingkat pendidikan, dan jenis pekerjaan pokok maupun sampingan dari masing-masing pembudidaya yang didapatkan dari wawancara langsung terhadap anggota kelompok pembudidaya rumput laut Segara Amerta di pantai kutuh. Jumlah pembudidaya yang digunakan adalah 27 orang yang merupakan anggota kelompok pembudidaya rumput laut Segara Amerta di pantai kutuh. Sedangkan data yang dikumpulkan berdasarkan pengukuran dalam kegiatan budidaya rumput laut adalah data pertumbuhan dan kualitas air budidaya rumput laut yaitu kedalaman, suhu, salinitas, $\mathrm{pH}$, oksigen terlarut (DO).

\section{Hasil dan Pembahasan}

\subsection{Karakteristik Pembudidaya}

Karakteristik pembudidaya berdasarkan data primer yang diperoleh dari 27 orang pembudidaya rumput laut meliputi: umur, tingkat pendidikan, dan jenis pekerjaan pokok maupun sampingan dari masing-masing pembudidaya.

\subsubsection{Umur Pembudidaya}

Umur merupakan salah satu faktor yang mempengaruhi produktivitas kerja seseorang (Panggabean, 2004). Kisaran umur pembudidaya rumput laut di Pantai Kutuh adalah 36-59 Tahun. Data kelompok umur pembudidaya dapat dilihat pada Tabel 1.

Tabel 1

Distribusi Umur Pembudidaya di Pantai Kutuh Tahun 2015

\begin{tabular}{|c|c|c|c|}
\hline No. & $\begin{array}{c}\text { Kelompok } \\
\text { Umur }\end{array}$ & $\begin{array}{c}\text { Jumlah } \\
\text { (Orang) }\end{array}$ & $\begin{array}{c}\text { Persentase } \\
(\mathbf{\%})\end{array}$ \\
\hline 1. & $35-40$ & 2 & 7,41 \\
\hline 2. & $41-45$ & 5 & 18,52 \\
\hline 3. & $46-50$ & 5 & 18,52 \\
\hline 4. & $51-55$ & 14 & 51,85 \\
\hline 5. & $56-60$ & 1 & 3,70 \\
\hline & TOTAL & 27 & 100 \\
\hline
\end{tabular}

Sumber: Diolah dari data primer

Tabel 1 menunjukkan bahwa pembudidaya rumput laut di Pantai Kutuh masih tergolong usia produktif. Pitoyo dan Hasmi (2013) menyatakan bahwa usia dibawah 15 tahun tergolong usia muda, usia 15-64 tahun tergolong usia produktif dan usia di atas 64 tahun tergolong usia tua.

\subsubsection{Tingkat Pendidikan Pembudidaya}

Pendidikan merupakan salah satu faktor yang mempengaruhi produktivitas kerja seseorang, karena dari pendidikan, seseorang akan mendapatkan keterampilan untuk bekerja (Panggabean, 2004). Tingkat pendidikan tertinggi pembudidaya rumput laut adalah SMA. Data tingkat pendidikan pembudidaya dapat dilihat pada Tabel 2.

Tabel 2

Distribusi Tingkat Pendidikan Pembudidaya di Pantai Kutuh Tahun 2015

\begin{tabular}{|c|l|r|r|}
\hline No. & Tingkat Pendidikan & $\begin{array}{c}\text { Jumlah } \\
\text { (Orang) }\end{array}$ & $\begin{array}{c}\text { Persentase } \\
(\%)\end{array}$ \\
\hline 1. & Tidak Sekolah & 4 & 14,81 \\
\hline 2. & SD & 7 & 25,93 \\
\hline 3. & SMP & 2 & 7,41 \\
\hline 4. & SMA & 14 & 51,85 \\
\hline & TOTAL & 27 & 100,00 \\
\hline
\end{tabular}

Sumber: Diolah dari data primer

Tabel 2 menunjukkan bahwa sebanyak 51,85\% pembudidaya rumput laut adalah lulusan SMA, 7,41\% lulusan SMP, 25,93\% lulusan SD, dan sisanya tidak bersekolah. Namun demikian, pembudidaya tetap dapat melakukan budidaya rumput laut dengan baik melalui pengalaman dan pengajaran yang didapat dari keluarga. Selain itu, sering dilakukan pelatihan-pelatihan mengenai cara berbudidaya rumput laut yang dilakukan oleh instansi pemerintah kepada anggota kelompok pembudidaya rumput laut di Pantai Kutuh.

Bapak Nyoman Sarma dalam wawancara mengatakan bahwa pemerintah sering memberikan pelatihan tentang 
cara berbudidaya rumput laut yang baik untuk mendapatkan hasil yang melimpah. Hampir setiap tahun ada program pemerintah untuk para pembudidaya rumput laut di Pantai Kutuh. Program terakhir yang sudah dilaksanakan adalah pelatihan cara menanam rumput laut yang benar pada tahun 2014 .

\subsubsection{Pekerjaan Pokok dan Sampingan Pembudidaya}

Pekerjaan pokok pembudidaya di Pantai Kutuh adalah sebagai pembudidaya rumput laut. Hasil budidaya rumput laut yang didapat pembudidaya lebih besar dibandingkan dengan pekerjaan lainnya. Selain bekerja sebagai pembudidaya rumput laut, pembudidaya juga memiliki pekerjaan sampingan yang dapat menambah penghasilan keluarga. Hal ini karena tidak diperlukan waktu banyak dalam berbudidaya rumput laut, sehingga pembudidaya dapat melakukan pekerjaan lain selain berbudidaya rumput laut. Pembudidaya biasanya mengecek rumput laut pada waktu air surut setiap harinya untuk memastikan kondisi rumput laut masih dalam keadaan baik. Selebihnya, pembudidaya mengerjakan pekerjaan sampingan sesuai dengan jenis pekerjaan sampingan masing-masing. Beberapa pembudidaya mempunyai pekerjaan sampingan yaitu beternak sapi, nelayan, pemandu wisata dan buruh proyek. Data pekerjaan sampingan pembudidaya dapat dilihat pada Tabel 3 .

Tabel 3

Distribusi Pekerjaan Sampingan Pembudidaya di Pantai Kutuh Tahun 2015

\begin{tabular}{|c|l|c|r|}
\hline No. & \multicolumn{1}{|c|}{$\begin{array}{c}\text { Pekerjaan } \\
\text { Sampingan }\end{array}$} & $\begin{array}{c}\text { Jumlah } \\
\text { (Orang) }\end{array}$ & $\begin{array}{c}\text { Persentase } \\
(\%)\end{array}$ \\
\hline 1. & Beternak sapi & 11 & 40,74 \\
\hline 2. & Nelayan & 7 & 25,93 \\
\hline 3. & Pemandu wisata & 5 & 18,52 \\
\hline 4. & Buruh proyek & 4 & 14,81 \\
\hline & TOTAL & 27 & 100,00 \\
\hline
\end{tabular}

Sumber: Diolah dari data primer

\subsection{Kegiatan Budidaya Rumput Laut}

Kegiatan budidaya rumput laut di Pantai Kutuh masih tetap dilakukan walaupun Pantai Kutuh atau yang lebih populer disebut Pantai Pandawa sudah berkembang menjadi daerah pariwisata. Jenis rumput laut yang dikembangkan di Pantai Kutuh adalah rumput laut jenis barong (Halymenia sp.). Hal ini karena rumput laut jenis barong memiliki beberapa kelebihan dibandingkan jenis rumput laut jenis lainnya yang sudah pernah dibudidayakan di Pantai Kutuh yaitu Eucheuma cotonii dan Glacilaria sp.. Kelebihan rumput laut jenis barong yaitu pertumbuhannya cepat, tidak diserang penyakit iceice dan tidak disukai oleh predator rumput laut, sehingga pembudidaya mendapatkan hasil panen yang lebih baik dibandingkan jenis rumput laut lainnya (Robledo dan Pelegrin, 2010). Gambar rumput laut jenis Halymenia sp. dapat dilihat pada Gambar 1.

Masa tanam rumput laut jenis barong adalah 15 hari. Metode penanaman rumput laut yang digunakan di Pantai Kutuh adalah lepas dasar (off-bottom method). Bibit yang ditanam berukuran 150 gram dengan jarak tanam $25 \mathrm{~cm}$. Bibit rumput laut awal yang digunakan dalam penelitian berasal dari pembudidaya rumput laut setempat. Penanaman rumput laut dilakukan satu kali masa tanam pada lahan yang disewa dari pembudidaya setempat.

Berdasarkan data hasil penelitian menunjukkan bahwa rata-rata pertumbuhan Rumput Laut Halymenia sp. selama 15 hari adalah sebesar $105,67 \%$ atau $7 \%$ /hari atau 10,57 gram/hari. Hasil pertambahan berat yang didapatkan pada penelitian menunjukkan bahwa pertumbuhan rumput laut di pantai kutuh tergolong baik. Menurut Winarno (1996) laju pertumbuhan rumput laut yang dianggap cukup menguntungkan adalah diatas 3\% pertambahan berat per hari. Peningkatan berat Rumput Laut Halymenia sp. dapat dilihat pada Gambar 2.

Bapak Nyoman Karma mengatakan dalam wawancara bahwa para pembudidaya lebih memilih menanam rumput laut jenis Halymenia sp. dibandingkan dengan rumput laut jenis Eucheuma cotonii. Hal ini karena keuntungan yang

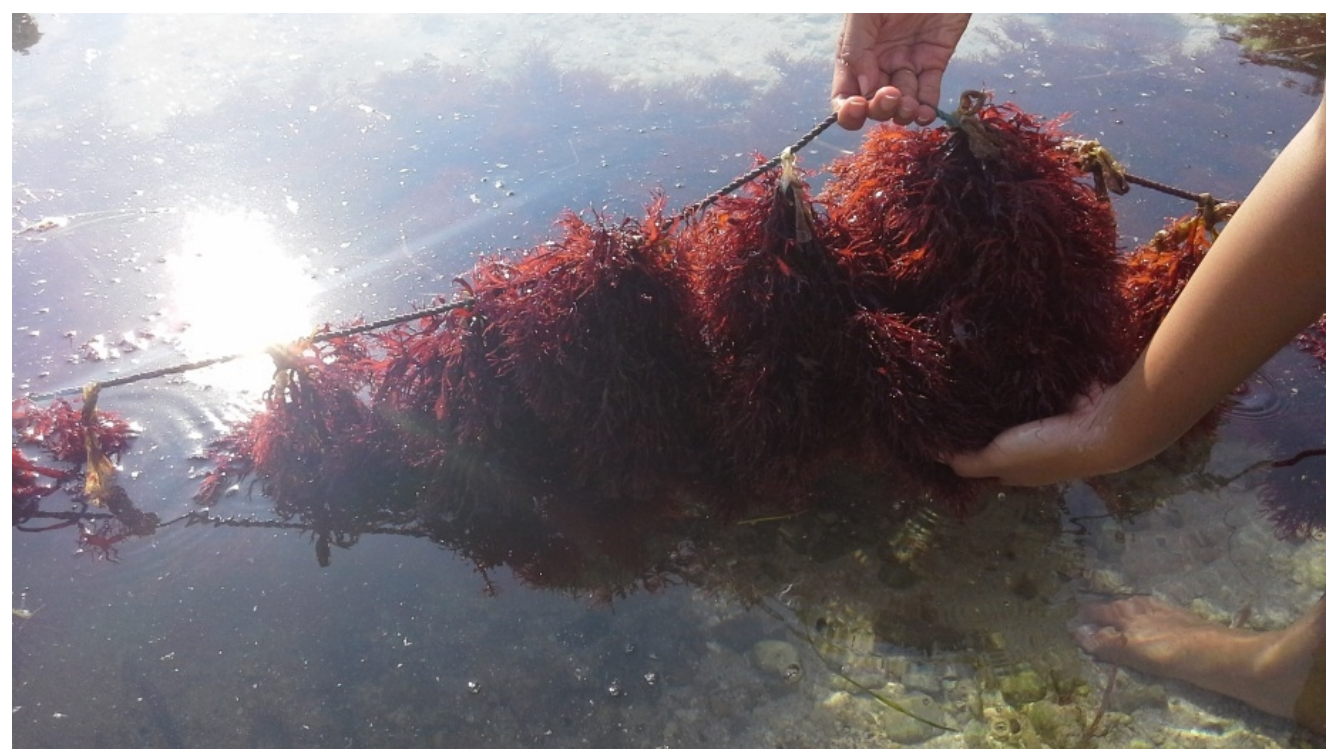

Gambar 1. Rumput Laut Jenis Halymenia sp. 


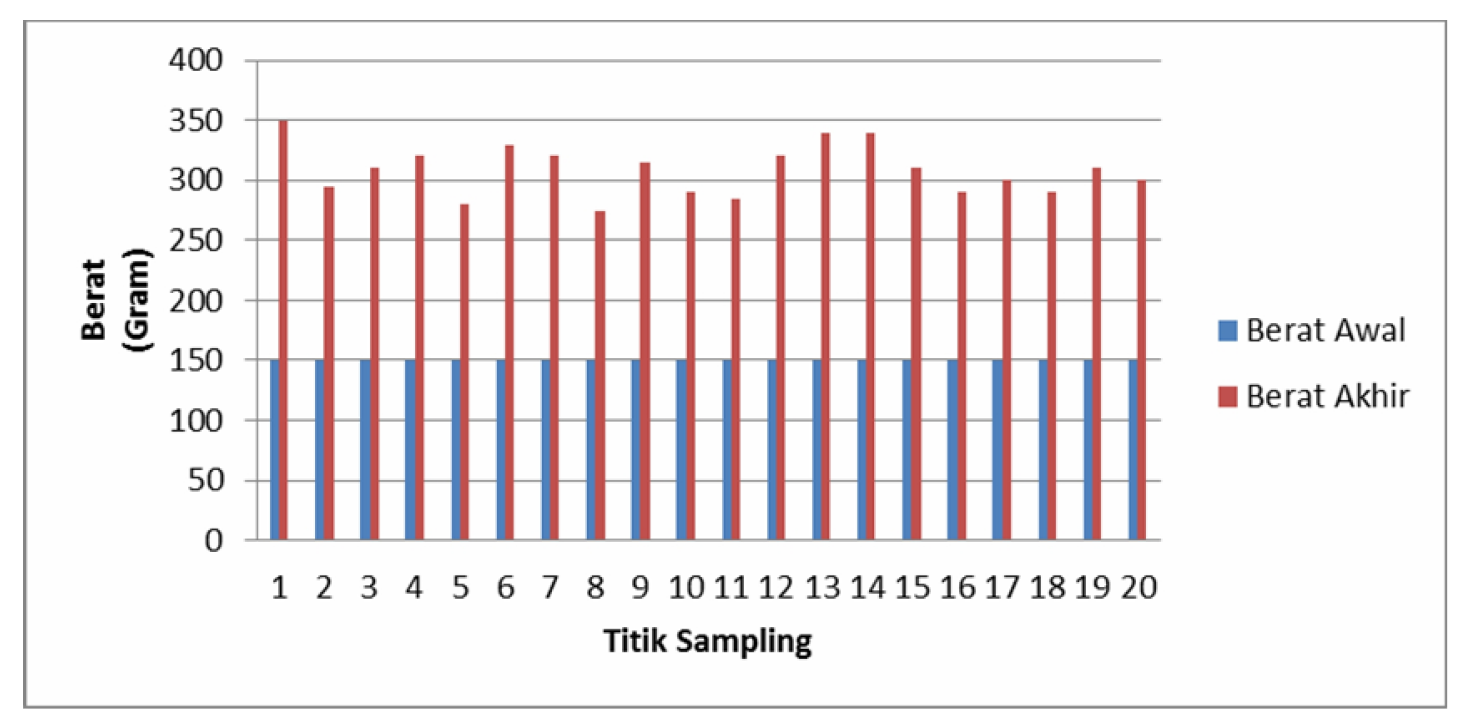

Gambar 2. Grafik Pertambahan Berat Halymenia sp. pada Setiap Titik Sampling

didapatkan lebih banyak dan masa tanamnya lebih singkat. Harga jual $1 \mathrm{~kg}$ rumput laut kering jenis Halymenia sp. adalah Rp. 11.000,00 - Rp. 13.000,00 sedangkan rumput laut kering jenis Eucheuma cotonii Rp. 7.000,00 - Rp. 9.000,00. Masa tanam rumput laut jenis Halymenia sp. adalah 15 hari sedangkan masa tanam rumput laut jenis Eucheuma cotonii adalah 30 hari. Selain itu rumput laut jenis Halymenia sp. lebih aman dari serangan predator karena rasanya tidak disukai oleh predator dibandingkan dengan rumput laut jenis Eucheuma cotonii. Berdasarkan alasan-alasan tersebut, petani lebih memilih untuk menanam rumput laut jenis Halymenia sp. walaupun masih ada beberapa pembudidaya rumput laut yang masih tetap menanam rumput laut jenis Eucheuma cotonii sebagai sampingan.

Pengambilan data kualitas air dilakukan sebanyak dua kali yaitu pada saat kondisi air surut dan kondisi air pasang. Sampling dilakukan pada tiga stasiun yang berdekatan dengan lokasi penanaman rumput laut. Data kualitas air hasil penelitian selanjutnya dibandingkan dengan tabel kelayakan budidaya rumput laut yang dikeluarkan oleh Bakosurtanal (1996).

Berdasarkan hasil perbandingan data kualitas air hasil pengukuran di Pantai Kutuh dengan tabel kelayakan budidaya rumput laut yang dikeluarkan oleh Bakosurtanal (1996) menunjukkan bahwa kondisi kualitas air pada lokasi budidaya rumput laut di Pantai Kutuh termasuk dalam Kategori I yang berarti bahwa kondisi perairan di Pantai Kutuh termasuk dalam kondisi perairan optimum untuk pertumbuhan rumput laut. Burdames dan Ngangi (2014) menyatakan bahwa salah satu kunci keberhasilan budidaya rumput laut adalah pemilihan lahan budidaya rumput laut yang tepat. Hal ini disebabkan produksi dan kualitas rumput laut dipengaruhi oleh faktor-faktor ekologis (oseanografis dan parameter kualitas air).

Kondisi perairan Pantai Kutuh yang tergolong optimum untuk pertumbuhan rumput laut ternyata memberikan dampak yang berbeda terhadap pertumbuhan rumput laut jenis Halymenia sp. dan rumput laut jenis Eucheuma cotonii. Pertumbuhan rumput laut jenis Halymenia sp. lebih baik dibandingkan dengan pertumbuhan rumput laut jenis Eucheuma cotonii. Hal ini menandakan bahwa terdapat faktor lain selain kualitas air yang mempengaruhi pertumbuhan rumput laut yaitu daya tahan rumput laut terhadap serangan penyakit. Largo $d k k$. (1995) menyatakan bahwa ketika rumput laut mengalami stress akan memudahkan infeksi patogen. Pada keadaan stress, rumput laut akan membebaskan substansi organik yang menyebabkan thallus berlendir dan merangsang bakteri tumbuh melimpah.

\subsection{Perkembangan Usaha Budidaya Rumput Laut di Pantai Kutuh}

Berdasarkan hasil wawancara terhadap pembudidaya rumput laut yang ada di Pantai Kutuh, diketahui bahwa pembudidaya masih tetap memilih menjadi pembudidaya rumput laut sebagai pekerjaan utama. Alasan utama pembudidaya adalah penghasilan yang didapatkan dari hasil budidaya rumput laut lebih tinggi dibandingkan dengan penghasilan yang didapatkan dari hasil pekerjaan sampingan masing-masing pembudidaya. Bapak Nyoman Sarma dalam wawancara menyatakan bahwa penghasilan yang didapatkan dari hasil budidaya rumput laut dapat mencapai 5 juta rupiah/bulan sedangkan hasil dari bekerja sebagai buruh, nelayan atau beternak sapi tidak bisa melebihi 5 juta rupiah/bulan.

Pembudidaya rumput laut menjual rumput laut dalam keadaan kering. Rumput laut jenis Halymenia sp. dijual kepada pengepul asal Nusa Dua dengan harga Rp. $11.000,00$ - Rp 13.000,00. Dengan harga tersebut pembudidaya mendapatkan keuntungan rata-rata sebesar Rp 5 juta pada setiap bulannya. Hal tersebut yang menjadi alasan utama pembudiaya rumput laut lebih memilih menanam rumput laut jenis Halymenia sp. dibandingkan dengan rumput laut jenis lainnya.

Berdasarkan hasil wawancara dari pembudidaya rumput laut dan hasil pengukuran pertumbuhan dan parameter kualitas air di Pantai Kutuh menunjukkan bahwa rumput laut jenis Halymenia sp. memiliki potensi yang sangat besar untuk dikembangkan sebagai salah satu daerah penghasil rumput laut yang dapat meningkatkan nilai produksi budidaya rumput laut di Bali khususnya dan 
Indonesia pada umumnya. Namun demikian, terdapat kendala dalam pengembangan usaha budidaya rumput laut di Pantai Kutuh yaitu pembudidaya kehilangan pasar untuk menjual rumput laut kering. Pengepul yang berasal dari Nusa Dua saat ini tidak lagi membeli rumput laut kering karena pabrik di negara tujuan ekspor tidak lagi membeli rumput laut kering jenis Halymenia sp..

Pembudidaya rumput laut menjual rumput laut kering jenis Halymenia sp. terakhir pada bulan September 2015. Alasan pabrik di negara tujuan ekspor berhenti membeli rumput laut kering jenis Halymenia sp. tidak diketahui pasti oleh para pembudidaya. Walaupun demikian, pembudidaya tetap menyimpan rumput laut kering jenis Halymenia sp. agar dapat dijual apabila ada yang membeli rumput laut kering jenis Halymenia sp.

\section{Simpulan}

Kesimpulan dari penelitian ini adalah (1) umur pembudidaya masih tegolong produktif, (2) sebagian besar tingkat pendidikan pembudidaya adalah lulusan SMA, (3) pekerjaan utama pembudidaya ada budidaya rumput laut jenis Halymenia sp. dan pekerjaan sampingan pembudidaya adalah beternak sapi, nelayan, pemandu wisata dan buruh proyek. Berdasarkan data hasil penelitian, diketahui bahwa pertumbuhan dan kualitas air budidaya rumput laut jenis Halymenia sp. tergolong baik, namun pengembangan usaha budidaya rumput laut jenis Halymenia sp. mengalami kendala dalam hal pemasaran rumput laut kering hasil budidaya.

\section{Ucapan terimakasih}

Atas asung kerta wara nugraha Ida Sang Hyang Widhi Wasa, penelitian ini dapat terlaksana dengan baik. Penelitian ini dapat terlaksana atas dana dari Fakultas Kelautan dan Perikanan, Universitas Udaya. Penulis mengucapkan terimakasih kepada semua pihak yang telah membantu penelitian ini, mulai dari penyusunan proposal, pelaksanaan penelitian sampai penulisan laporan.

\section{Daftar Pustaka}

Arthana, W., D. Pertami, G. Hendrawan, I.Y. Perwira, D.B Wijayanto, D. Ulinuha. 2012. Pemetaan Potensi Kawasan Budidaya Rumput Laut di Perairan Tenggara Pulau Bali. Universitas Udayana. Bali

Aslan, L. M., 2006. Budidaya Rumput Laut. Kanisius . Yogyakarta.

Bakosurtanal. (1996). Pengembangan Prototipe Wilayah Pesisir dan Marin Kupang - Nusa Tenggara Timur. Pusat Bina Aplikasi Inderaja dan Sistem Informasi Geografis. Cibinong.

Burdames, Y. dan E. L. A. Ngangi. 2014. Kondisi Lingkungan Perairan Budi Daya Rumput Laut di Desa Arakan, Kabupaten Minahasa Selatan. Budidaya Perairan 2(3): 69-75.

KKP (Kementerian Kelautan dan Perikanan). 2011. Kelautan dan Perikanan dalam Angka 2011. Kementerian Kelautan dan Perikanan. Jakarta. 118 hlm.

Largo, D.B., Fukami, K., and Nishijima, T. 1995. Occasional Pathogenic Bacteria Promoting ice-ice Disease in The Carrageenan-Producing Red Algae Kappaphycus alvarezii and Eucheuma denticulatum (Solieriaceae, Gigartinales, Rhodophyta). Journal of Applied Phyciology 7: 545-554.

Panggabean, Mutiara S. 2004. Manajemen Sumber Daya Manusia. Ghalia Indonesia: Jakarta

Pitoyo, A.J. dan E. Hasmi. 2013. Menjadi Produktif di Usia Produktif. Direktorat Kerjasama Pendidikan Kependudukan $B K K B N$. Jakarta: $53 \mathrm{hlm}$.

Robledo, D dan Y. F. Pereglin. 2010. Prospects for the cultivation of economically important carrageenophytes in Southeast Mexico. J Appl Phycol DOI 10.1007. Spinger.

Sumariadhi, N.W. dan I. W. Wijayasa. 2012. Dampak Pariwisata di Nusa Lembongan. Jurnal Perhotelan dan Pariwisata 2 (2); $23-47$

Suwariati, N.W.E., I.K.B. Susrusa dan I.K. Rantau. 2014. Perbedaan Pendapatan Usahatani Rumput Laut Eucheuma spinosum dan Eucheuma cottonii di Desa Kutuh Kecamatan Kuta Selatan. E-Jurnal Agribisnis dan Agrowisata 3(1); 2231

Winarno, 1996. Teknik Pengolahan Rumput Laut. Pustaka Sinar Harapan. Jakarta.

(C) 2016 by the authors; licensee Udayana University, Indonesia. This article is an open access article distributed under the terms and conditions of the Creative Commons Attribution license (http://creativecommons.org/licenses/by/3.0/). 